\title{
Mengenal Bayi dengan Sindrom Putus Obat: Laporan Kasus
}

\author{
Dina Indah Mulyani, Rinawati Rohsiswatmo \\ **Departemen Ilmu Kesehatan Anak, FKUI, RS Dr. Cipto Mangunkusumo, Jakarta
}

\begin{abstract}
Sindrom putus obat pada bayi baru lahir merupakan kumpulan gejala dan tanda putus obat, dengan karakteristik manifestasi iritabilitas sistem saraf pusat, gangguan sistem autonom, sistem respiratorik serta sistem gastrointestinal tergantung pada masing-masing obat penyebab. Penegakan diagnostik didasarkan pada riwayat penggunaan obat terlarang selama ibu hamil, pemeriksaan fisis dan pemeriksaan penunjang. Keterlambatan diagnosis dapat meningkatkan risiko komplikasi perinatal dan pasca natal yang dapat dialami bayi diantaranya ketuban pecah dini, gawat janin, prematuritas, bayi berat lahir rendah, asfiksi, dan sudden infant death syndrome (sindrom kematian mendadak pada bayi). Dengan sistem skoring yang baik, tata laksana yang diberikan dapat mencapai tujuan yaitu menghilangkan pengaruh obat tanpa menimbulkan gejala putus obat yang berat. (Sari Pediatri 2009;11(2):94-101).
\end{abstract}

Kata kunci: sindrom putus obat, neonatal abstinence syndrom score (NASS)

S indrom putus obat pada bayi baru lahir merupakan kumpulan gejala dan tanda putus obat dengan karakteristik manifestasi tergantung pada masing-masing obat penyebab. Terdapat dua tipe sindrom putus obat pada bayi baru lahir yaitu, sindrom yang terjadi akibat penggunaan narkotika, psikotropika dan zat adiktif (NAPZA) selama ibu hamil (prenatal) dan sindrom yang terjadi akibat pemutusan penggunaan obat yang digunakan untuk terapi nyeri (misal fentanil) pada bayi baru lahir (pascanatal). ${ }^{1,2}$

Tulisan ini lebih dipusatkan pada sindrom putus

\section{Alamat korespondensi}

Dr. Rinawati Rohsiswatmo, Sp.A(K). Divisi Perinatologi. Departemen Ilmu Kesehatan Anak FKUI-RSCM. Jl. Salemba No.6, Jakarta 10430. Telepon/Fax. 021-3146811. obat bayi baru lahir yang terjadi akibat penggunaan NAPZA selama ibu hamil. Gejala dan tanda klinis putus obat pada umumnya timbul pada 48-72 jam pertama, berupa iritabilitas pada sistem saraf pusat, gangguan neurobehavioural, dan aktivasi sistem simpatis yang abnormal. ${ }^{3,4}$ Diagnosis sindrom tidak mudah untuk ditegakkan karena riwayat penggunaan NAPZA selama ibu hamil seringkali disangkal dan sulit untuk menelusuri secara rinci jenis obat yang dipakai, lama penggunaan, dan frekuensi penggunaan obat. Selain itu secara klinis gejala dan tanda putus obat pada bayi baru lahir menyerupai penyakit lain seperti sepsis, hipokalsemia dan hipoglikemi. Berikut sebuah laporan kasus sindrom putus obat pada seorang bayi cukup bulan yang lahir dari ibu dengan riwayat pemakaian heroin selama tiga tahun. 


\section{Kasus}

Seorang bayi laki-laki, usia 30 jam, dirujuk dari RS $\mathrm{P}$ dengan diagnosis tersangka sepsis. Bayi lahir di RS P dari ibu usia 19 tahun, usia kehamilan 38 minggu, melalui bedah kaisar atas indikasi presentasi kepala dengan disproporsi sefalo-pelvik. Berat lahir 2800 gram, panjang lahir $48 \mathrm{~cm}$, lingkar kepala $33 \mathrm{~cm}$, nilai Apgar menit pertama 8 menit kelima 9. Ketuban dipecahkan saat bedah kaisar, ditemukan berwarna jernih, tidak berbau.

Riwayat kelahiran di RS P: bayi dirawat di ruangan bayi karena ibu masih menderita nyeri pasca operasi. Saat usia 1-2 jam, bayi terlihat rewel dan malas minum. Tidak diberi obat apapun karena petugas medis menilai hal tersebut sebagai proses adaptasi bayi. Pada Usia 4-6 jam, bayi semakin rewel, menangis terus, suhu sub febris, malas minum dengan refleks hisap yang tidak adekuat disertai gerakan seperti tremor di kedua lengan dan kaku seluruh tubuh. Selanjutnya bayi mendapat diazepam per rektal, dapat tertidur sebentar tetapi kemudian gejala klinis seperti yang telah disebutkan timbul kembali. Dokter yang merawat mencurigai bayi tersebut mengalami sepsis dengan diagnosis banding meningitis. Dilakukan pemeriksaan darah, gula darah, elektrolit, darah tepi, C-Reactive Protein (CRP), perbandingan neutrofil imatur dan neutrofil total (rasio IT), biakan darah serta pemberian antibiotik. Didapatkan hasil pemeriksaan darah tidak menunjukkan sepsis, tidak ditemukan hipoglikemi, dan tidak ada gangguan elektrolit.

Mengingat keterbatasan fasilitas dan kondisi bayi yang tidak membaik, saat usia 30 jam, bayi dirujuk ke RS H untuk tata laksana lebih lanjut. Saat diterima di RS H, bayi terlihat rewel, menangis terus-menerus dengan tangisan yang melengking dan bersin-bersin. Dari pemeriksaan fisis didapatkan suhu sub-febris, tonus otot meningkat, dijumpai gerakan seperti tremor spontan yang simetris pada kedua lengan, serta refleks hisap yang tidak adekuat. Berdasarkan pemeriksaan fisis, riwayat perawatan bayi sebelumnya dan hasil pemeriksaan penunjang yang telah dilakukan, terdapat kecurigaan bahwa bayi mengalami gejala putus obat sehingga kemudian dilakukan anamnesis mendalam terhadap ibu mengenai riwayat penggunaan obat saat ibu hamil. Dari anamnesis didapatkan bahwa ibu adalah seorang pengguna heroin selama tiga tahun, kondisi ibu tersebut tidak diketahui oleh keluarga.

Selanjutnya dilakukan pemeriksaan skoring terhadap bayi menggunakan neonatal abstinence syndrome score (NASS) dan saat usia 30 jam didapatkan skor 10 (Tabel 1). ${ }^{5}$ Bayi mendapatkan pacifier, dibedong/dibungkus rapat dengan kain, tubuh bayi dielus/diusap untuk menenangkan tetapi bayi tetap rewel dan menangis terus menerus. Ditemukan refleks hisap yang tidak adekuat maka pemberian nutrisi dilakukan secara parenteral. Penilaian berikutnya dilakukan setiap 2 jam, didapatkan skor NASS bayi meningkat menjadi 15 yaitu bayi tidak dapat tidur, berkeringat dan terdapat demam ringan. Pemberian terapi suportif tidak berhasil dan terdapat peningkatan skor NASS maka selanjutnya bayi mendapatkan terapi medikamentosa berupa morfin per oral dengan dosis pertama pemberian $0,6 \mathrm{mg} / \mathrm{kg}$ berat lahir $/ 6$ jam (dosis yang dianjurkan $0,5-0,7 \mathrm{mg} / \mathrm{kg}$ berat lahir/6 jam).

Dalam penilaian 6 jam berikutnya, gejala dan tanda klinis bayi belum dapat terkontrol (kriteria terkontrol apabila rata-rata skor $<8$ dalam tiga kali penilaian berturut-turut) sehingga frekuensi pemberian morfin dinaikkan menjadi 0,6 mg/kg berat lahir/4 jam. Dalam monitor berikutnya ditemukan rata-rata skor NASS bayi turun menjadi 7 selama tiga kali penilaian berturut-turut. Bayi tampak lebih tenang, tidur lebih lama, gerakan tremor berkurang, refleks hisap bayi mulai adekuat sehingga pemberian minum dapat ditingkatkan, dan nutrisi parenteral dihentikan pada hari berikutnya. Dosis morfin kemudian dipertahankan selama tiga hari.

Selama tiga hari pemberian morfin, skor NASS bayi turun secara bertahap serta menunjukkan perubahan klinis yang lebih baik. Bayi dapat tidur lebih lama, lebih tenang, dan minum dengan baik. Pada perawatan hari kelima, dilakukan weaning (penurunan) dosis morfin $10 \%$ dari dosis maksimal yaitu $0,6 \mathrm{mg} /$ $\mathrm{kg}$ berat lahir $/ 4$ jam menjadi $0,54 \mathrm{mg} / \mathrm{kg}$ berat lahir $/ 4$ jam. Dosis weaning pertama dipertahankan selama tiga hari, demikian seterusnya dilakukan weaning setiap tiga hari disesuaikan dengan skor NASS. Dosis weaning terakhir $0,18 \mathrm{mg} / \mathrm{kg}$ berat lahir/4 jam dicapai pada hari perawatan ke 26. Setelah dosis weaning terakhir, jadwal pemberian morfin diubah menjadi 6 jam dan dipertahankan selama tiga hari. Pada hari perawatan ke 29, pemberian morfin dihentikan dan bayi diobservasi selama tiga hari. Selama dalam perawatan dilakukan pemeriksaan HIV terhadap ibu dengan hasil HIV non reaktif sehingga bayi tidak mendapatkan terapi antiretroviral. Bayi pulang pada usia 33 hari, sudah dapat minum dengan baik dan mengalami kenaikan 
berat badan. Pengasuhan bayi selanjutnya diberikan kepada kakek dan nenek sementara ibu menjalani rehabilitasi. Saat ini bayi berusia 6 bulan dengan pertumbuhan dan perkembangan sesuai umur.

\section{Diskusi}

Sindrom putus obat pada bayi baru lahir merupakan kumpulan gejala dan tanda putus obat dengan karakteristik manifestasi berupa iritabilitas susunan saraf pusat, gangguan sistem autonom, sistem respiratorik serta sistem gastrointestinal tergantung dari obat penyebab. ${ }^{1,2,4,6}$ Gejala dan tanda putus obat muncul pada 55\%-94\% bayi dengan riwayat penggunaan NAPZA saat ibu hamil. ${ }^{2}$ Angka kejadian pemakaian obat terlarang pada ibu hamil $4 \%$ berdasarkan survei di Amerika Serikat pada tahun 2006, sedangkan studi di Inggris $15 \%$ urin ibu hamil positif mengandung obat terlarang. ${ }^{4,7}$

Beberapa golongan obat yang dapat menyebabkan sindrom putus obat pada bayi baru lahir adalah narkotik golongan opiat (kodein, metadon, fentanil, heroin), golongan obat yang bersifat stimulant (amfetamin, kokain), golongan obat depresan susunan saraf pusat (alkohol, barbiturat, benzodiazepin, cannabis/ganja), golongan selective serotonin reuptake inhibitors/SSRIs (fluoksetin). ${ }^{1,2,3,4}$ Narkotik golongan opiat merupakan penyebab yang paling sering dijumpai dan memiliki manifestasi yang lebih jelas. ${ }^{2}$

Secara umum, setiap obat yang digunakan selama kehamilan memiliki potensi untuk melewati plasenta dan terakumulasi pada tubuh janin dan cairan amnion. Pada saat proses kelahiran, transfer substansi obat via plasenta terhenti akan tetapi metabolisme dan ekskresi obat dalam tubuh bayi baru lahir masih tetap berlangsung. ${ }^{3,8,9}$ Zat adiktif umumnya bersifat lipofilik dan mempunyai berat molekul rendah sehingga dapat melewati plasenta dan masuk ke dalam sirkulasi darah janin. Selain itu pada janin obat mempunyai waktu paruh yang lama karena proses metabolik dan ekskresi ginjal yang belum matang. Sebagian besar substansi zat adiktif berikatan dengan reseptor di susunan saraf pusat (SSP) atau mempengaruhi pelepasan dan re-uptake beberapa neurotransmitter sehingga dapat memiliki pengaruh langsung maupun tidak langsung terhadap perkembangan sel otak janin. 3,6,8

Manifestasi klinis pada sindrom putus obat pada bayi baru lahir mengenai multisistem dan bervariasi tergantung pada obat yang digunakan ibu. Sistem organ yang paling sering terlibat adalah sistem saraf pusat (irritabilitas, tangisan melengking/high pitched cry, hiperaktif refleks, hipertonus otot, tremor, kejang umum, dan gangguan tidur), sistem gastrointestinal (gangguan makan, muntah, diare, dan dehidrasi), sistem autonom (takikardi, instabilitas suhu, dan berkeringat) serta sistem respiratorik (takipnea, apnea, bersin). Gejala dan tanda klinis putus obat pada umumnya timbul pada 48-72 jam pertama, namun dapat timbul lambat pada usia empat minggu. Gejala subakut dapat bertahan sampai dengan enam bulan., ${ }^{2,3,4}$ Kapan manifestasi klinis timbul dipengaruhi oleh beberapa faktor yaitu jenis obat, dosis, frekuensi penggunaan, waktu terakhir kali ibu menggunakan obat-obatan, metabolisme dan ekskresi metabolit aktif obat dalam tubuh bayi, serta kapan terakhir kali bayi terpapar obat saat intrauterin. Bayi yang mengalami paparan obat terakhir kali lebih atau sama dengan satu minggu sebelum dilahirkan memiliki risiko mengalami gejala putus obat yang relatif lebih rendah. ${ }^{3,4,9}$ Penggunaan beberapa obat (polydrugs) menimbulkan manifestasi yang lebih berat. ${ }^{10,11}$

Beberapa kondisi ibu dan bayi dapat meningkatkan faktor risiko terjadi sindrom putus obat pada bayi baru lahir diantaranya, riwayat sosial-ekonomi rendah, riwayat perawatan antenatal yang kurang adekuat, usia ibu yang masih remaja, tingkat pendidikan ibu, riwayat penggunaan obat-obatan pada kehamilan sebelumnya, riwayat penggunaan obat-obatan pada pasangan hidup ibu, riwayat penyakit menular seksual (hepatitis B, AIDS, sifilis, gonorhoe), riwayat korioamnionitis, riwayat partus prematur, pertumbuhan janin terhambat, riwayat kejang, dan apneu yang tidak diketahui sebabnya. ${ }^{3,10}$

Untuk menentukan berat-ringan gejala putus obat yang dialami bayi digunakan sistem skoring dengan tujuan untuk menilai gejala dan tanda putus obat pada bayi baru lahir secara sistematik, objektif, berkala serta menentukan pemberian terapi medikamentosa. Sistem skoring yang banyak digunakan adalah Modifikasi Sistem Skoring Finnegan (neonatal abstinence syndrom score/NASS) yang terdiri dari 21 gejala putus obat yang paling sering dijumpai (Tabel 1 dan 2). Penilaian dilakukan minimal 30 menit setelah pemberian minum dengan interval setiap 4 jam, tetapi apabila skor $\geq 8$ dibutuhkan interval penilaian yang lebih singkat (setiap 2 jam). ${ }^{2,12,13}$

Pada kasus dengan kecurigaan kuat terjadi putus obat pada bayi baru lahir, perlu dilakukan beberapa 
Tabel 1. Lembar skoring modifikasi sistem skoring Finnegan (Neonatal Abstinence Syndrome Score/NASS)

\begin{tabular}{|c|c|c|c|c|c|c|c|c|}
\hline Sistem & Gejala dan tanda & \multirow{2}{*}{$\begin{array}{c}\text { Skor } \\
2\end{array}$} & \multicolumn{3}{|c|}{ Pagi } & \multicolumn{3}{|c|}{ Siang } \\
\hline \multirow{15}{*}{ 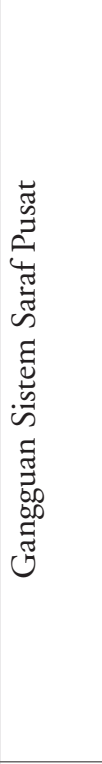 } & Menangis berlebihan dengan/tanpa nada tinggi $<5$ menit & & & & & & & \\
\hline & Menangis terus menerus dengan/tanpa nada tinggi $>5$ menit & 3 & & & & & & \\
\hline & Tidur $<1$ jam setelah pemberian minum & 3 & & & & & & \\
\hline & Tidur $<2$ jam setelah pemberian minum & 2 & & & & & & \\
\hline & Tidur $<3$ jam setelah pemberian minum & 1 & & & & & & \\
\hline & Hiperaktifitas refleks Moro & 2 & & & & & & \\
\hline & Hiperaktifitas refleks Moro yang nyata & 3 & & & & & & \\
\hline & Tremor ringan saat terganggu & 1 & & & & & & \\
\hline & Tremor sedang-berat saat terganggu & 2 & & & & & & \\
\hline & Tremor ringan walaupun tidak ada gangguan & 3 & & & & & & \\
\hline & Tremor sedang-berat walaupun tidak ada gangguan & 4 & & & & & & \\
\hline & Peningkatan tonus otot & 1 & & & & & & \\
\hline & Ekskoriasi (dagu, lutut, siku, ibu jari kaki, hidung) & 1 & & & & & & \\
\hline & Kejang mioklonik (kedutan/sentakan tungkai dan lengan) & 3 & & & & & & \\
\hline & Kejang umum & 5 & & & & & & \\
\hline \multirow{10}{*}{ 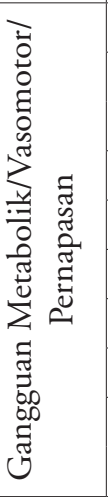 } & Berkeringat & 1 & & & & & & \\
\hline & Demam $37,2-38,3^{\circ} \mathrm{C}$ & 1 & & & & & & \\
\hline & Hipertermi $>38,4^{\circ} \mathrm{C}$ & 2 & & & & & & \\
\hline & Sering menguap (>3-4 kali/interval skoring) & 1 & & & & & & \\
\hline & Mottled & 1 & & & & & & \\
\hline & Hidung tersumbat & 1 & & & & & & \\
\hline & Bersin (>3-4 kali/interval scoring) & 1 & & & & & & \\
\hline & Napas cuping hidung & 2 & & & & & & \\
\hline & Frekuensi napas $>60 /$ menit & 1 & & & & & & \\
\hline & Frekuensi napas $>60 /$ menit dengan retraksi & 2 & & & & & & \\
\hline \multirow{9}{*}{ 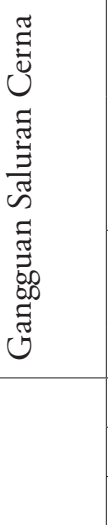 } & Menghisap berlebihan & 1 & & & & & & \\
\hline & Menghisap kurang kuat/tidak terkoordinasi & 2 & & & & & & \\
\hline & Regurgitasi ( $\geq 2$ kali selama/setelah pemberian nutrisi) & 2 & & & & & & \\
\hline & Muntah proyektil & 3 & & & & & & \\
\hline & Diare (tampak seperti gumpalan susu atau biji) & 2 & & & & & & \\
\hline & Tinja cair & 3 & & & & & & \\
\hline & Skor total & & 10 & 15 & 13 & 10 & 10 & 7 \\
\hline & Tanggal/jam & & 8 & 10 & 12 & 14 & 16 & 18 \\
\hline & Inisial penilai & & & & & & & \\
\hline
\end{tabular}

Sumber: Finnegan LP. Neonatal abstinence syndrome:assessment and pharmacotherapy. Nelson N, editor. Current therapy in neonatal-perinatal medicine. Edisi Kedua. Ontario:BC Decker;1990 
Tabel 2. Penuntun penilaian gejala putus obat pada bayi baru lahir

\begin{tabular}{|c|c|}
\hline Gejala & Penilaian \\
\hline Tangis nada tinggi & $\begin{array}{l}\text { Bayi dinilai bila menangis berkepanjangan, walaupun tanpa nada tinggi. Nilai } 2 \text { bila tangis } \\
\text { nada tinggi sebagai puncaknya. Nilai } 3 \text { bila tangis nada tinggi sepanjang tangisan }\end{array}$ \\
\hline Tidur & $\begin{array}{l}\text { Merupakan skala meningkatnya perburukan, bayi sebaiknya hanya mendapat } 1 \text { nilai dari } \\
3 \text { tingkat perburukan. Seorang bayi prematur dalam } 3 \text { jam minum paling banyak dapat } \\
\text { tidur } 2,5 \text { jam. }\end{array}$ \\
\hline Refleks Moro & $\begin{array}{l}\text { Nilai bayi bila menunjukkan jitteriness (tremor ritmik yang simetris dan tidak disadari) } \\
\text { dari kedua tangan selama atau pada akhir refleks moro. Nilai } 3 \text { bila jitteriness dan klonus } \\
\text { (sentakan yang tidak disadari berulang-ulang) dari kedua tangan dan/atau lengan yang } \\
\text { muncul selama atau setelah refleks awal }\end{array}$ \\
\hline Tremor & $\begin{array}{l}\text { Merupakan skala meningkatnya perburukan, bayi sebaiknya hanya mendapat } 1 \text { nilai dari } \\
4 \text { derajat perburukan. Istilah tidak diganggu menunjukkan bayi yang sedang tidur atau } \\
\text { istirahat dalam inkubator }\end{array}$ \\
\hline Peningkatan tonus otot & $\begin{array}{l}\text { Nilai bila tonus otot berlebihan atau otot menjadi kaku dan bayi menunjukkan resistensi } \\
\text { bermakna terhadap gerakan pasif seperti bayi tidak mengalami head leg ketika ditarik ke } \\
\text { posisi duduk atau terdapat fleksi yang kaku pada lengan dan tungkai bayi (tidak dapat } \\
\text { mencapai posisi sedikit ekstensi pada saat lengan dan tungkai bayi diekstensi) }\end{array}$ \\
\hline Ekskoriasi & $\begin{array}{l}\text { Aberasi kulit yang terjadi akibat gesekan konstan terhadap permukaan kain tempat tidur. } \\
\text { Nilai hanya diberikan bila ekskoriasi pertama kali muncul, meningkat atau muncul } \\
\text { baru }\end{array}$ \\
\hline Kejang mioklonik & $\begin{array}{l}\text { Nilai diberikan bila kontraksi otot ireguler yang tidak disadari dan terjadi secara tiba-tiba } \\
\text { (biasanya melibatkan satu kelompok otot) }\end{array}$ \\
\hline Kejang umum & $\begin{array}{l}\text { Pada bayi baru lahir kejang umum lebih sering terlihat berupa ekstensi tonik semua } \\
\text { alat gerak, kadang dapat terjadi pada satu sisi. Gerakan alat gerak yang tidak umum } \\
\text { dapat menyertai kejang. Pada alat gerak atas dapat berupa gerakan seperti berenang atau } \\
\text { mendayung. Pada anggota gerak bawah seperti gerakan mengayuh. Tanda lain yang tidak } \\
\text { nyata dapat berupa mata menatap tajam, gerakan cepat mata tidak disadari, mengunyah, } \\
\text { melengkungkan punggung dan mengepalkan tangan }\end{array}$ \\
\hline Berkeringat & $\begin{array}{l}\text { Nilai diberikan bila berkeringat terjadi spontan dan tidak disebabkan bayi memakai baju } \\
\text { tebal/dibungkus berlebihan atau suhu ruangan yang tinggi }\end{array}$ \\
\hline Hipertermi & $\begin{array}{l}\text { Suhu sebaiknya diperiksa di ketiak. Demam yang ringan }\left(37,2-38,3^{\circ} \mathrm{C}\right) \text { merupakan indikasi } \\
\text { awal produksi panas sebagai akibat meningkatnya tonus otot dan tremor }\end{array}$ \\
\hline Mottled & $\begin{array}{l}\text { Nilai bila mottled (tampak area berbercak merah muda dan pucat atau putih) muncul } \\
\text { pada daerah dada, batang tubuh, lengan atau tungkai bayi }\end{array}$ \\
\hline Menghisap berlebihan & $\begin{array}{l}\text { Nilai bila terdapat menghisap berlebihan/tidak terkontrol, peningkatan refleks susur atau } \\
\text { usaha untuk menghisap ibu jari maupun kepalan tangan (lebih dari sekedar bayi lapar } \\
\text { pada umumnya) }\end{array}$ \\
\hline Kemampuan minum buruk & $\begin{array}{l}\text { Nilai bila bayi menunjukkan menghisap yang berlebihan sebelum minum maupun } \\
\text { menghisap jarang selama minum sehingga hanya mendapat sejumlah kecil ASI atau susu } \\
\text { formula dan atau menunjukkan refleks menghisap tidak terkordinasi (kesulitan menghisap } \\
\text { dan menelan). Bayi prematur yang memerlukan tube feeding sebaiknya tidak dinilai untuk } \\
\text { kemampuan minum buruk sesuai dengan usia gestasi }\end{array}$ \\
\hline
\end{tabular}

Sumber: Finnegan LP. Neonatal abstinence syndrome:assessment and pharmacotherapy. Nelson N, editor. Current therapy in neonatal-perinatal medicine. Edisi Kedua. Ontario:BC Decker;1990

pemeriksaan penunjang diantaranya pemeriksaan urin bayi baru lahir. Pemeriksaan urin ini paling sering dilakukan tetapi memiliki potensi hasil positif palsu yang tinggi karena hasil positif hanya didapatkan pada bayi dengan paparan obat yang paling baru, selain itu hasil negatif palsu seringkali didapatkan bila ibu 
berhenti mengkonsumsi obat beberapa hari sebelum melahirkan atau spesimen urin yang digunakan bukan urin yang didapat sesaat setelah bayi baru lahir. Pemeriksaan kadar obat pada cairan mekonium, merupakan pemeriksaan yang lebih mudah dan sensitif dibandingkan pemeriksaan urin bayi walaupun lebih mahal dan masih jarang dilakukan. Pemeriksaan analisis rambut merupakan jenis pemeriksaan yang paling mahal dan hanya tersedia di pusat kesehatan rujukan. Metabolit obat dapat dideteksi dalam rambut bayi sampai usia 2-3 bulan. Selain pemeriksaan tersebut pada bayi dengan ibu pemakai obat terlarang perlu dilakukan uji tapis terhadap hepatitis B dan C serta penyakit menular seksual seperti HIV terutama pada ibu dengan riwayat penggunaan jarum suntik bersama. ${ }^{3,10,14}$

Secara umum, pengobatan untuk putus obat pada bayi baru lahir terdiri dari pengobatan suportif dan pengobatan medikamentosa. Tata laksana awal harus dimulai dengan pengobatan suportif karena pengobatan medikamentosa dapat memperpanjang lama rawat dan menjadikan bayi terpapar oleh obatobat yang tidak diperlukan. ${ }^{4,6}$ Kesulitan yang sering dijumpai dalam diagnosis sindrom putus obat adalah manifestasi klinis yang muncul seringkali menyerupai gangguan metabolik atau infeksi sehingga bayi pada awalnya diobati sesuai kecurigaan, namun klinis tidak membaik. Pengobatan suportif yang diberikan diantaranya dengan meredupkan pencahayaan ruang rawat bayi untuk mengurangi stimulasi sensoris dan iritabilitas, perawatan yang lembut serta menjaga stabilitas suhu. Pemberian nutrisi merupakan pengobatan suportif yang perlu dilakukan untuk menstabilkan kondisi bayi pada fase akut tanpa perlu menambahkan pengobatan medikamentosa. Nutrisi diberikan dengan formula hiperkalori dalam jumlah kecil tapi sering untuk memenuhi kebutuhan kalori tambahan. Kebutuhan kalori ditambahkan karena terdapat peningkatan aktivitas, menangis, berkurangnya waktu tidur, regurgitasi, dan diare..$^{4,6,12}$
Terapi medikamentosa didasarkan pada berat-ringan gejala putus obat. Tujuan pemberian terapi untuk menghilangkan pengaruh obat tanpa menimbulkan gejala putus obat yang berat serta mengembalikan pola tidur dan minum yang adekuat. ${ }^{2,3,10}$ Indikasi pemberian medikamentosa adalah skoring NASS 8 atau lebih, penurunan berat badan berlebihan, dehidrasi akibat diare atau ketidak-mampuan bayi untuk minum, demam yang bukan disebabkan oleh infeksi atau kejang serta bila dengan pengobatan suportif tidak dapat menurunkan skoring NASS di bawah 8. Obat pilihan yang digunakan untuk sindrom putus obat neonatus adalah morfin dan fenobarbital.

Morfin diberikan pada bayi yang lahir dari ibu dengan ketergantungan opiat dengan dosis awal pemberian morfin tergantung pada skor NASS bayi (Tabel 3.1). ${ }^{12}$ Perubahan dosis obat dihitung berdasarkan berat lahir bukan berat saat pengobatan. Penurunan dosis obat (weaning) dilakukan perlahan sehingga bayi dapat beradaptasi dengan gejala ringan putus obat, dapat minum, dan tidur dengan baik (Tabel 3.2)..$^{2,3,4,12}$ Proses penurunan dosis obat bervariasi tergantung pada toleransi bayi sehingga lama rawat bayi bervariasi. Selama pemberian morfin harus dilakukan monitor ketat terhadap kemungkinan apne karena morfin memiliki efek depresi sistem pernafasan. ${ }^{4,5,12}$ Fenobarbital merupakan obat lini pertama pada ibu yang tidak diketahui jenis obatnya atau pengguna nonopiat atau ibu dengan intoksikasi alkohol atau dapat diberikan bila morfin tidak efektif mengurangi gejala dan tanda putus obat. ${ }^{12}$ Bayi dengan ibu pengguna obatobatan sebaiknya dirawat di unit perinatologi untuk diobservasi, namun beberapa penelitian menunjukkan rawat gabung dengan pengawasan yang ketat petugas dari kesehatan dan keluarga dapat menurunkan angka kejadian dan derajat keparahan putus obat pada bayi baru lahir, serta meningkatkan ikatan antara ibu dan bayi. ${ }^{12,15}$ Setelah bayi dipulangkan, hendaknya orangtua diberi pengetahuan bila terdapat gejala putus obat, karena meskipun jarang, putus obat neonatus

Tabel 3.1. Dosis pemberian morfin untuk terapi sindrom putus obat

\begin{tabular}{ll}
\hline Skor & Dosis morfin \\
\hline Skor $\geq 8$ dalam 3 kali penilaian berturut-turut & $0,5 \mathrm{mg} / \mathrm{kg}$ berat lahir/4-6 jam* \\
Skor $\geq 12$ dalam 2 kali penilaian berturut-turut & $0,5-0,7 \mathrm{mg} / \mathrm{kg}$ berat lahir/4-6 jam* \\
\hline $\begin{array}{l}\text { * Bila gejala putus obat pada bayi tidak membaik dalam } 6 \text { jam pemberian obat, maka frekuensi pemberian dosis obat dapat diubah menjadi } 4 \text { jam sebelum } \\
\text { dilakukan peningkatan dosis }\end{array}$ \\
Sumber: Royal Women's Hospital Clinician's Handbook. Care of babies born to substances dependent mothers. Australia: Royal Women's Hospital; 2009
\end{tabular}


Tabel 3.2. Pedoman weaning dosis morfin untuk terapi sindrom putus obat

Jika bayi mendapatkan dosis per 6 jam

Gejala putus obat di rumah sakit - Pertahankan dosis selama 72 jam

- Turunkan dosis sebesar 10\% dari total dosis maksimal yang diberikan setiap 72 jam jika kondisi klinis mengalami perbaikan

- Setelah dosis harian mencapai 0,10-0,12 mg/kgBL/hari, pemberian morfin

dapat dihentikan

- Skor NASS tetap dinilai selama 72 jam setelah morfin dihentikan

Jika bayi mendapatkan dosis per 4 jam

Perawatan rumah sakit - Pertahankan dosis selama 72 jam

- Turunkan dosis sebesar 10\% dari total dosis maksimal yang diberikan setiap 72 jam hingga mencapai dosis $0,2 \mathrm{mg} / \mathrm{kgBL} / \mathrm{hari}$

- Frekuensi pemberian dosis diubah dari 4 jam/hari menjadi 6 jam/hari

- Skor NASS tetap dinilai selama 72 jam setelah morfin dihentikan

Sumber: Royal Women's Hospital Clinician's Handbook. Care of babies born to substances dependent mothers. Australia: Royal Women's Hospital; 2009

Tabel 3.3. Pemulangan bayi dengan sindrom putus obat

Tidak terdapat permasalahan medis lain

Tidak terdapat pengajuan hukum terhadap ibu pengguna NAPZA

Bayi tidak membutuhkan penilaian lebih lanjut dengan skoring putus obat

Orang tua sudah siap/ mampu untuk mengurus bayinya

Dukungan penuh dan pendampingan dari keluarga dalam pengasuhan bayi

Lingkungan/rumah yang layak untuk mendukung tumbuh kembang bayi

Cukup ketersediaan tenaga di rumah untuk membantu mengurus bayi

Pertimbangkan perlindungan anak terhadap kemungkinan terjadinya kekerasan terhadap anak di rumah

Sumber : Royal Women's Hospital Clinician's Handbook. Care of babies born to substances dependent mothers. (modifikasi) Australia:

Royal Women's Hospital; 2009

dapat terjadi pada usia 4 minggu. ${ }^{9} 10$ Hal-hal yang perlu dipertimbangkan saat memulangkan bayi tertera pada Tabel 3.3. ${ }^{12}$

Prognosis bayi dengan sindrom putus obat tergantung pada obat penyebabnya. Secara umum pada beberapa kepustakaan disebutkan bahwa penggunaan obat terlarang dapat menyebabkan perubahan sel dan molekul yang mengarah pada perubahan sistem saraf, transmisi saraf, dan perubahan formasi otak secara keseluruhan sehingga dapat menimbulkan gejala sisa sebagai efek jangka panjang berupa keterlambatan perkembangan mental, kesulitan belajar, perubahan perilaku, dan cara pikir (kognitif). $4,8,14,16$

Data mengenai follow-up jangka panjang terhadap pertumbuhan dan perkembangan bayi masih terbatas. Bayi dengan gejala putus obat akibat golongan opiat saat usia 1-2 tahun, laju pertumbuhan dapat sesuai umur, walaupun beberapa diantaranya berada di bawah rata-rata. Di usia 5-6 tahun, perkembangan motorik dan mental juga dapat sesuai umur. Usia 9 tahun, anak dengan riwayat putus obat karena opiat cenderung memiliki beberapa skor penilaian proses perkembangan bicara yang lebih rendah dibandingkan anak normal. Namun demikian kondisi anak dengan luaran yang baik dapat meningkat secara signifikan bila diobati dengan tepat serta ditunjang dengan lingkungan pengasuhan yang positif. ${ }^{3}$ Maka bayi baru lahir dari ibu dengan riwayat penggunaan obat terlarang harus diketahui agar dapat diterapi dengan tepat serta di follow-up dengan baik sehingga dapat menurunkan risiko efek jangka panjang yang mempengaruhi tumbuh kembang anak.

\section{Kesimpulan}

Manifestasi klinis yang menyerupai penyakit lain menjadikan petugas kesehatan terutama dokter anak harus dapat mewaspadai kemungkinan sindrom putus obat pada bayi baru lahir. Pada kasus yang berat akan disertai dengan gangguan autonom, gangguan sistem syaraf pusat, gangguan respiratorik, serta gangguan 
gastrointestinal (gangguan pemberian minum) yang berat sehingga bayi berpotensi mengalami gagal tumbuh bahkan sampai dengan kematian. Anamnesis, pemeriksaan fisis serta pemerikaan penunjang yang baik penting dalam menegakkan diagnosis serta memilih tata laksana yang tepat. Hal yang perlu diperhatikan adalah sindrom putus obat pada bayi baru lahir akibat penggunaan NAPZA saat ibu hamil diperkirakan akan semakin meningkat dikemudian hari, mengingat penggunaan NAPZA di masyarakat semakin meningkat..

\section{Daftar Pustaka}

1. Hamdan AH. Neonatal abstinence syndrome. Diunduh dari http:/lemedicine.medscape.com. Diakses tanggal 19 Agustus 2009.

2. Burgos EA. Neonatal abstinence syndrome. Neo Rev 2009;10:e223-9.

3. Alpan G. Infant of a drug-abusing mother. Dalam: Gomella TL, penyunting, Neonatology:management, procedures, on-call problems, diseases and drugs. Edisi Keenam. United States of America: The McGraw-Hill Companies, Inc; 2009.h.540-9.

4. American Academy of Pediatrics Committee on Drugs. Neonatal drug withdrawal. Pediatrics 1998;101:107988.

5. Finnegan LP. Neonatal abstinence syndrome: assessment and pharmacotherapy. Dalam: Nelson N, penyunting. Current therapy in neonatal-perinatal medicine. Edisi Kedua. Ontario: BC Decker; 1990.h.314-20.

6. Johnson K, Gereda C, Greenough A. Treatment of neonatal abstinence syndrome. Arch Dis Child Fetal Neonatal 2003;88:F2-5.
7. O'Donnel M, Nassar N, Leonard H, Hagan R, Mathews $\mathrm{R}$, Patterson, dkk. Increasing prevalence of neonatal withdrawal syndrome: population study of maternal factors and child protection involvement. Pediatrics 2009; 123:e614-21.

8. Chasnoff IJ. Prenatal substance exposure: maternal screening and neonatal identification and management. Neo Rev 2003;4:e223-35.

9. Ostrea EM, Gause S, Raymundo AL, Stevens M. Drug screening of newborns by meconium analysis: a large scale, prospective, epidemiologic study. Pediatrics 1992;89:107-13.

10. Matic A. Neonatal abstinence syndrome. Acta Medica Medianae 2008;47:55-9.

11. Bada HS, Bauer CR, Shankaran S, Lester B, LL Wright, LP Finnegan, dkk. Central and autonomic system signs with in utero drug exposure. Arch Dis Child Fetal Neonatal Ed 2002;87:F106-12.

12. Royal Women's Hospital Clinician's Handbook. Care of babies born to substances dependent mothers. Australia: Royal Women's Hospital; 2009.h.123-30.

13. Obrien C, Hunt R, Jeffery HE. Measurement of movement is an objective method to assist in assessment of opiate withdrawal in newborns. Arch Dis Child Fetal Neonatal Ed 2004;89:F305-9.

14. Day E, George S. Management of drug misuse in pregnancy. Adv in Psych Treat 2005;11:253-61.

15. Saiki T, Lee S, Hannam S, Greenough A. Neonatal abstinence syndrome: pascanatal ward versus neonatal unit management. Eur J Pediat. 14 Mei 2009. Diunduh dari http://www.springerlink.com. Diakses tanggal 19 Agustus 2009.

16. Wang M. Perinatal drug abuse and neonatal drug withdrawal. Diunduh dari http://emedicine.medscape.com. Diakses tanggal 19 Agustus 2009. 